\title{
Stability of Nanocomposite Edible Films Based on Polysaccharides and Vitamin C from Agroindustrial Residue
}

\author{
José Augusto de Almeida Nascimento ${ }^{\text {, Laiane Keylla Silva Gomes }}{ }^{a}$, Dirliane Santos Duarte ${ }^{b}$ Maria \\ Auxiliadora Coelho de Limac, Douglas de Britto ${ }^{c *(D)}$ \\ aPrograma de Pós-graduação em Ciência dos Materiais, Universidade Federal do Vale do São \\ Francisco, Petrolina, PE, Brasil \\ ${ }^{b}$ Instituto Federal do Sertão de Pernambuco, Petrolina, PE, Brasil \\ ${ }^{c}$ Centro de Pesquisa Agropecuária do Tropico Semiárido, Embrapa Semiárido, Petrolina, PE, Brasil
}

Received: January 21, 2019; Accepted: March 09, 2019

\begin{abstract}
The agroindustrial residue from the production of acerola pulp is rich in residual vitamin C. Thus, aiming its extraction and stabilization, this work proposed the nanoparticle (NP) encapsulation via ionic gelation with subsequent preparation of nanocomposites (NC) film based on galactomannan matrix. NP were characterized and their stabilities were evaluated under different storage conditions (incidence of light, temperature and oxidizing atmosphere). The results by Dynamic Light Scattering (DLS) and Scanning Electron Microscopy (SEM) indicated homogeneous morphology, spherical shape and size of $\sim 220 \mathrm{~nm}$. Regarding the stability, the UV-visible spectrophotometric analysis showed a much lower degradation rate for encapsulated vitamin $C$, resulting in more than $30 \%$ of preservation compared with the non-encapsulated systems at the end of 15 th day of storage. In agreement, the NC films also resulted in preservation of vitamin $\mathrm{C}$ mainly for the test in high temperature, which maintained about $80 \%$ of the initial concentration, whereas in the non-encapsulated condition this value fell to $45 \%$. The morphological analysis of these films by SEM indicated good distribution of the NP in the galactomannan matrix. Thus, the results indicate the feasibility of using the encapsulation method to stabilize vitamin $\mathrm{C}$ extracted from the agroindustrial residue of acerola.
\end{abstract}

Keywords: Chitosan, Galactomannan, Nanoencapsulation, Acerola, Mesquite gum.

\section{Introduction}

The good use of agroindustrial residue has motivated many studies and applications. From the environmental point of view, the correct destination of these residues is desired in order to minimize the environmental impact and accumulation of waste ${ }^{1}$. On the other hand, from the technological point of view, these residues can be driven for extraction of molecules and macromolecules with bioactive properties, having potential for economic exploitation. They are substances, for example, as polysaccharides, lipids, proteins, polyphenols, vitamins, among several other classes ${ }^{2}$. In this scope, byproduct from winery industry has been studied as low-cost source of valuable polyphenols compounds with high-added value ${ }^{3}$. Its use extends to applications in various fields, including cosmetic, nutraceutical, chemical, and food industries. Antimicrobial activity from byproducts components is much explored due the possibility to preserve food and avoid contamination as found, for example, in pine knot extract with high antifungal activity ${ }^{4}$. Antioxidant property is also focused in these residues, as that found in the oil extrated from green coffee seeds ${ }^{5}$. In the nanobiotechnology

*e-mail: douglas.britto@embrapa.br field, the agro-industrial byproducts also offer promising applications ${ }^{6}$.

A type of residue very common in the San Francisco Valley (Brazilian Northeast) is the residue of acerola (Malpighia emarginata D.C.) from fruit pulping processing. This residue, although having vitamins, minerals, fibers, antioxidants and phenolics compounds in its composition, is wasted in most factories. The reprocess of these components is so-much likely for application in food areas such as jams, jellies, juices, cereal bars, cakes, as well as for others industrial application ${ }^{2,7}$. In the case of acerola, a previous study showed that in the processed residue still having a significant amount of residual vitamin $\mathrm{C}^{8}$.

This vitamin can be recovered through extraction and stabilization processes, since vitamins, especially vitamin $\mathrm{C}$, are sensitive and unstable compounds that lose their functions when exposed to inadequate temperature ${ }^{9}$, oxidizing atmosphere $\left(\mathrm{O}_{2}\right)^{10}$, humidity or light ${ }^{11}$. One solution to this is to employ polysaccharides with chelating activity, such as chitosan, which has the ability to bind to various types of substances and enable their extraction and stabilization. In addition, these polysaccharides can also form nanoparticles (NP) that considerably preserve the stability of these vitamins ${ }^{12}$.

The use of nanoparticles (NP) is very promising in the food area, since it can encapsulate and delivery substances 
with nutraceutical property ${ }^{13,14}$. In the case of vitamins, encapsulation may be even more interesting because they are sensitive and unstable under certain conditions ${ }^{15}$. For this, one versatile system is based on the polyelectrolyte property of chitosan that allows its interaction with charged and polar species, forming stable nanohydrogel with opposite charged species, e.g., tripolyphosphate (TPP) ${ }^{16}$. This system has been used to encapsulate and stabilize several class of active compounds ${ }^{12,17}$, with potential application in food packaging and post-harvest active coatings.

Further, the NP can be introduced into edible films matrices to form nanocomposite (NC), which can extend the preservation with application as active packaging for fruit and vegetable coating ${ }^{18}$. Nowadays, NC edible films based on polysaccharides have been arouse as an important alternative to the use of non-renewable resources. In addition, such films can assign nutraceutical activity properties to the substrate and increase food preservation capacity to external factors ${ }^{19}$. A material with potential to form edible film is the galactomannan polysaccharide present in mesquite gum seed (Prosopis juliflora), a very common tree in the Brazilian Northeast ${ }^{20}$. This application is an interesting alternative, low cost and extends the potential of exploitation of this species classified as invasive in the Caatinga biome ${ }^{21}$.

In this way, this work had as main objective the extraction of vitamin $\mathrm{C}$ from the agroindustrial residue of the production of acerola pulp and its concomitant stabilization by nanoencapsulation via ionic gelation from chitosan and TPP. Subsequently, NC films containing NP of chitosan and vitamin $\mathrm{C}$ were prepared from galactomannans obtained by casting. Techniques as Dynamic Light Scattering, Scanning Electron Microscopy, UV-visible spectrophotometric, Infrared Spectroscopy and Mechanical Analysis were used to characterize respectively the nanoparticle, morphological and diffusional aspect of the material. With this study, it was possible to offer viable alternatives for the use of agroindustrial residues with potential for the formation of edible films, being able to be an active ingredient in food formulations, both for human consumption and for animal feed.

\section{Material and Methods}

\subsection{Materials}

The residues from the processing of acerola (Malpighia emarginata D.C.) pulp were provided by Niagro-Nichirei do Brasil Agrícola Ltda, (Petrolina, PE) and composed from cultivars 'Okinawa' and 'Flor Branca'. Sodium tripolyphosphate (TPP), $85 \%$; and chitosan of medium molecular weight, $75-85 \%$ deacetylated were purchased from Sigma-Aldrich, St. Louis, Missouri, USA. Acetic acid, 99.7\%, (HAc); oxalic acid dihydrate P.A.; metaphosphoric acid P.A. and L $(+)$ ascorbic acid P.A. (AA) were acquired from Vetec, Rio de Janeiro, Brazil. Hydrochloric acid, 37\% was purchased from Alphatec, São José dos Pinhais, Brazil. Ethanol P.A., 99.5\%, was purchased from Sciavicco, Belo Horizonte, Brazil. Such commercially purchased solvents and reagents were used without prior purification. For the preparation of the nanocomposite films, the galactomannan (GLM) was extracted from the mesquite gum seed collected at Embrapa Semiárido (Petrolina, PE) ${ }^{22}$.

\subsection{Extraction and quantification of vitamin $C$ in the byproduct}

The basic methodology to extract vitamin $\mathrm{C}$ consisted in weighing $5.0 \mathrm{~g}$ of the acerola residue in Falcon tube and subjecting it to extraction with $40.0 \mathrm{~cm}^{3}$ of aqueous solution of oxalic acid at $0.5 \%(\mathrm{w} / \mathrm{v})$ (Table 1$)$. After manual stirring for dispersion of the residue, the mixture was centrifuged at $10,000 \mathrm{rpm}$ for $5 \mathrm{~min}$ and $8^{\circ} \mathrm{C}$ for separation of the solid residue and obtaining the supernatant rich in vitamin $\mathrm{C}$. Following, the volume was adjusted to $100.0 \mathrm{~cm}^{3}$ with the oxalic acid solution and an aliquot of $0.2 \mathrm{~cm}^{3}$ was taken, diluted in $10.0 \mathrm{~cm}^{3}$ of methaphosphoric acid solution at $1 \%(\mathrm{w} / \mathrm{v})$ and quantified by UV-visible spectrophotometry (Thermo Scientific, MultiSkan GO model). A calibration curve was previously set at $242 \mathrm{~nm}$ with AA in methaphosphoric acid solution. Other extractions systems based on chitosan solution were tested to allow the nanoencapsulation of vitamin C (Table 1).

The content of vitamin $\mathrm{C}$ in dry mass was estimated by valuating the humidity degree in the raw material by drying a known amount of sample $\left(1.0 \mathrm{~g}\right.$, triplicate) at $105^{\circ} \mathrm{C}$ for 24 hours. Based on the dried mass and the quantification of vitamin $\mathrm{C}$, the AA content was calculated. The results were expressed in $\mathrm{mg}$ of $\mathrm{AA} / 100 \mathrm{~g}$ of byproduct.

Table 1. Different systems used to extract vitamin C from the agroindustrial byproduct of acerola.

\begin{tabular}{|c|c|c|}
\hline Samples & First step (extraction) & $\begin{array}{l}\text { Second step (adjusting } \\
\text { to } 100 \mathrm{~cm}^{3} \text { ) }\end{array}$ \\
\hline $\begin{array}{l}\text { Extract } 1 \\
\text { (control) }\end{array}$ & $\begin{array}{c}40.0 \mathrm{~cm}^{3}, \text { oxalic acid } \\
0.5 \%(\mathrm{~m} / \mathrm{v})\end{array}$ & Oxalic acid, $0.5 \%(\mathrm{~m} / \mathrm{v})$ \\
\hline Extract 2 & $\begin{array}{l}50.0 \mathrm{~cm}^{3}, \text { chitosan, } 3.0 \\
\mathrm{mg} \mathrm{cm}-3 \text {, HAc aqueous } \\
\text { solution } 0.1 \%(\mathrm{v} / \mathrm{v})\end{array}$ & $\begin{array}{c}\text { HAc aqueous solution } \\
0.1 \%(\mathrm{v} / \mathrm{v})\end{array}$ \\
\hline Extract 3 & $\begin{array}{c}50.0 \mathrm{~cm}^{3} \text {, chitosan, } 3.0 \\
\mathrm{mg} \mathrm{cm} \text {, } \text {, HAc aqueous } \\
\text { solution } 0.1 \%(\mathrm{v} / \mathrm{v})\end{array}$ & Oxalic acid, $0.5 \%(\mathrm{~m} / \mathrm{v})$ \\
\hline Extract 4 & $\begin{array}{c}50.0 \mathrm{~cm}^{3}, \text { chitosan, } 3.0 \\
\mathrm{mg} \mathrm{cm}-3, \mathrm{HCl} \text { aqueous } \\
\text { solution } 0.1 \%(\mathrm{v} / \mathrm{v})\end{array}$ & $\begin{array}{c}\mathrm{HCl} \text { aqueous solution } \\
0.1 \%(\mathrm{v} / \mathrm{v})\end{array}$ \\
\hline Extract 5 & $\begin{array}{c}50.0 \mathrm{~cm}^{3}, \text { chitosan, } 3.0 \\
\mathrm{mg} \mathrm{cm}-3, \mathrm{HCl} \text { aqueous } \\
\text { solution } 0.1 \%(\mathrm{v} / \mathrm{v})\end{array}$ & Oxalic acid, $0.5 \%(\mathrm{~m} / \mathrm{v})$ \\
\hline
\end{tabular}




\subsection{Stabilization of vitamin C by nanoencapsulation}

In preliminary tests, the samples from Extracts 4 and 5 gave the best results. In this way, this condition (first step) was chosen for nanoencapsulation. Thus, $50.0 \mathrm{~cm}^{3}$ of chitosan solution $\left(3.0 \mathrm{mg} \mathrm{cm}^{-3}\right)$ in $0.1 \% \mathrm{HCl}(\mathrm{v} / \mathrm{v})$ rich in vitamin $C$ was subjected to the encapsulation process ${ }^{12}$ via ionotropic gelation with $50.0 \mathrm{~cm}^{3}$ of TPP $\left(1.2 \mathrm{mg} \mathrm{cm}^{-3}\right)$. For comparison, a control system was also prepared by dissolving $60.0 \mathrm{mg}$ of AA in $50.0 \mathrm{~cm}^{3}$ of acid chitosan solution. This solution was submitted to ionic gelation under the same conditions. The suspensions of NP were denominated $\mathrm{NP}_{\mathrm{ex}}$ and $\mathrm{NP}_{\mathrm{AA}}$ respectively for $\mathrm{NP}$ obtained from the extract of the byproduct and those obtained from AA.

\subsection{Preparation of nanocomposite films}

The NC films based on GLM solution were prepared from the suspensions of nanoparticles $\mathrm{NP}_{\mathrm{ex}}$ and $\mathrm{NP}_{\mathrm{AA}}$. For better results, the concentration of TPP was adjusted to 1.0 and $1.1 \mathrm{mg} \mathrm{cm}^{-3}$, respectively for the $\mathrm{NP}_{\mathrm{ex}}$ and $\mathrm{NP}_{\mathrm{AA}}$. Following, an aliquot of $20.0 \mathrm{~cm}^{3}$ from $\mathrm{NP}_{\mathrm{ex}}$ and $\mathrm{NP}_{\mathrm{AA}}$ was taken and powder GLM was added sufficient to get a solution at $5.0 \mathrm{mg}$ $\mathrm{cm}^{-3}$. The suspensions of GLM + NP were deposited in Petri dishes, frozen and lyophilized (L101 Liobras) for 24 hours. The lyophilization was necessary to decrease the degradation rate of vitamin $\mathrm{C}$ for further analysis that is prohibitive by the casting method due long term generally used. The NC films thus obtained were named $\mathrm{NC}_{\mathrm{ex}}$ and $\mathrm{NC}_{\mathrm{AA}}$, respectively, for the films obtained from $\mathrm{NP}_{\mathrm{ex}}$ and $\mathrm{NP}_{\mathrm{AA}}$. The experiment was carried out in duplicate. In addition, a control NC film was prepared in order to compare the relative degradation of vitamin C. For this, $30 \mathrm{mg}$ of ascorbic acid was added to the aqueous solution of GLM $\left(5 \mathrm{mg} \mathrm{cm}^{-3}\right)$ and the film obtained as described above. This sample was called $\mathrm{CF}_{\mathrm{AA}}$.

\subsection{Stability assessment of NP and NC in different conditions}

The stability of vitamin C in NP (aqueous suspension) and NC (lyophilized films) were evaluated by subjecting the systems to different storage conditions and evaluating aliquots at predetermined time intervals. The conditions were incidence of fluorescent light, temperature and $\mathrm{O}_{2}$ saturation. For exposure to light, NP suspensions and NC films were placed in an oven equipped with a constant photoperiod (Eletrolab brand, model EL202/E) at $25^{\circ} \mathrm{C}$, $24 \%$ humidity for 15 days and luminosity intensity of $5.88 \mathrm{k}$ lux. For temperature influence, NP and NC were placed in climatic chamber (Fitotec brand, model LT 2100 UTFP) at $35^{\circ} \mathrm{C}$ in the absence of light for 15 days. For oxygen influence (in absence of light, $25{ }^{\circ} \mathrm{C}$ ), the NP suspension was saturated with $\mathrm{O}_{2}$ for 10 minutes at every day analysis. For NC films, they were conditioned in a closed desiccator whose interior was evacuated and injected $\mathrm{O}_{2}$. The humidity was inferior to $10 \%$.

For quantification of vitamin $\mathrm{C}$ in NP suspension, $1.0 \mathrm{~cm}^{3}$ aliquots were centrifuged $\left(13,000 \mathrm{rpm}, 10 \mathrm{~min}, 10^{\circ} \mathrm{C}\right)$ and the vitamin $\mathrm{C}$ in the supernatant quantified by UV-visible spectrophotometry as described above. For quantification of vitamin $\mathrm{C}$ in the NC films, parts of the films $(\sim 20 \mathrm{mg})$ were extracted with aqueous ethanol solution $(50 \%)$ for 5 hours and the vitamin $\mathrm{C}$ present in the supernatant quantified similarly.

In addition, NP systems were compared with other relative degradations of vitamin $\mathrm{C}$, the first with $\mathrm{AA}$ in deionized water $\left(0.6 \mathrm{mg} \mathrm{cm}^{-3}\right)$ and the second with the supernatant of the acerola residue extracted with oxalic acid at $0.5 \%(\mathrm{~m} / \mathrm{v})$, being denominated $\mathrm{AA}_{\mathrm{wt}}$ and $\mathrm{VC}_{\mathrm{ox}}$, respectively.

\subsection{Additional characterization of NP suspension and nanocomposites}

The nanoparticles and nanocomposites were characterized regarding NP size, zeta potential, morphology, chemical characteristics and mechanical property.

The size and zeta potential were evaluated on Zetasizer $\mathrm{Nano}^{\circledR}$ ZS Zen 3600 equipment from Malvern Instruments Ltd., England, based on the Dynamic Light Scattering (DLS) technique. All analyzes were performed in triplicate at $25^{\circ} \mathrm{C}$.

For morphological analysis, the NP and NC suspensions were deposited in glass sheet, dried by casting and investigated by Scanning Electron Microscopy (SEM) in a TESCAN ${ }^{\mathbb{B}}$ equipment, model VEGA $3 \mathrm{XMU}$. It was used an accelerating voltage of $10 \mathrm{keV}$ and the sample coated with an ultrathin coating of gold by low vacuum sputter coating to avoid the accumulation of electrostatic charge. For best visualization of the nanoparticle, the $\mathrm{NP}_{\mathrm{AA}}$ and $\mathrm{NP}_{\mathrm{ex}}$ suspension were pretreated by cryogenic technique to preserve the NP structure. For this, the suspension was centrifuged at $20,000 \mathrm{rpm}$, the NP precipitated re-suspended in the cryogenic solution of sucrose at 5\% (w/v), frizzed and lyophilized. After, the dry sample was washed with deionized water for three times, re-suspended in deionized water and deposited in glass sheet.

For chemical analysis, Infrared Spectroscopy (FTIR) was used with $\mathrm{NC}$ thin films fixed directly on the equipment. The equipment was a Perkin Elmer $^{\circledR}$ model Spectrum 400 in the range $400-4000 \mathrm{~cm}^{-1}$, with average of 8 scanning and $1 \mathrm{~cm}^{-1}$ resolution.

For Mechanical Analysis, the films were cut and fixed in a paper template measuring $38 \times 25 \mathrm{~mm}$ with an opened window of $6 \times 12 \mathrm{~mm}$ for better handle the sample. The equipment was an $\mathrm{Emic}^{\circledR}$ DL 10000 universal testing machine with a load cell of $500 \mathrm{~N}$ and displacement rate of $5 \mathrm{~mm} / \mathrm{min}$. The films dimensions were $15 \mathrm{~mm}$ of length and $5 \mathrm{~mm}$ of width. The thickness of samples was measured with a hand micrometer. The thickness used was an average of six measurements ( $\sim 0.013 \mathrm{a} 0.088 \mathrm{~mm})$ taken randomly. 


\section{Results and Discussion}

Based on the quantification of vitamin $\mathrm{C}$ present in the extract and considering the average humidity degree of $85.8 \%$ found for the raw material, the AA was calculated, as shown in Table 2. The AA content varied slightly for each sample and is in accordance with reported in the literature ${ }^{7}$. Although, the AA content can vary greatly depending on the maturated stage of the fruit and the specific process used in industrial plant ${ }^{23}$. However, such values are superior that found for others fruits in natura, as pineapple $(34.6 \mathrm{mg} / 100 \mathrm{~g})$, cashew (219.3 mg/100 g), guava (99.2 mg/100 g), orange $(56.9 \mathrm{mg} / 100 \mathrm{~g})$ and mango $(65.5 \mathrm{mg} / 100 \mathrm{~g})^{24}$. This highlights the importance of this byproduct as source of vitamin $\mathrm{C}$.

Table 2. AA content in the agroindustrial byproduct of acerola.

\begin{tabular}{lcc}
\hline Samples & $\begin{array}{c}\text { AA content in wet } \\
\text { byproduct }(\mathrm{mg} / \mathrm{100g})\end{array}$ & $\begin{array}{c}\text { AA content in dry } \\
\text { byproduct }(\mathrm{mg} / 100 \mathrm{~g})\end{array}$ \\
\hline Extract 1 & $1,466.00$ & $10,355.00$ \\
Extract 2 & $1,426.00$ & $10,067.00$ \\
Extract 3 & $1,290.00$ & $9,115.00$ \\
Extract 4 & $1,370.00$ & $9,680.00$ \\
Extract 5 & $1,288.00$ & $9,090.00$ \\
\hline
\end{tabular}

\subsection{Stability of encapsulated vitamin $C$ in nanoparticles suspensions}

Based on the preliminary studies, the Extract 5 showed the best preservation activity (90\%) after three days of exposition under light when compared with others systems (near 60\%) and even with the oxalic acid control (78\%, Extract 1$)$. It is an important find, once it shows the possibility to use other acid than the acetic acid commonly used to solubilize the chitosan $^{16,25}$, having enhanced encapsulation property.

According, the vitamin $\mathrm{C}$ degradation in function of time was less expressive for the nanoencapsulated systems in comparison with non-encapsulated ones (Figure 1). For light influence (Figure 1a), considering the initial vitamin $\mathrm{C}$ concentration, the encapsulated condition $\mathrm{NP}_{\mathrm{ex}}$ and $\mathrm{NP}_{\mathrm{AA}}$ retained about $64 \%$ of the initial concentration on the fifteenth day. This value is high when compared to non-encapsulated systems, where the concentration reaches $48 \%$ and $31 \%$ respectively for $\mathrm{AA}_{\mathrm{wt}}$ and $\mathrm{VC}_{\mathrm{ox}}$, at the end of day $15^{\text {th }}$. Similarly, for the influence of temperature (Figure 1b), the encapsulated samples $\mathrm{NP}_{\mathrm{ex}}$ and $\mathrm{NP}_{\mathrm{AA}}$ exhibited a concentration equivalent to $66 \%$ of the initial amount, whereas for the non-encapsulated $\mathrm{VC}_{\mathrm{ox}}$ and $\mathrm{AA}_{\mathrm{wt}}$ reached $38 \%$ and $47 \%$, respectively, at the end of the 15 days. In agreement, the stability of vitamin $\mathrm{C}$ under action of $\mathrm{O}_{2}$ was greater for encapsulated systems (Figure 1c), in which the concentration reached about $56 \%$ of its initial value. Non-encapsulated systems have degraded at a slightly higher rate. These results demonstrate the effectiveness of encapsulation in protecting vitamin $\mathrm{C}$ as described before ${ }^{25-28}$.

\subsection{Size and zeta potential variations}

The NP size for zero day showed that the control system $\mathrm{NP}_{\mathrm{AA}}$ presented smaller average size when compared to encapsulated extract, $\mathrm{NP}_{\mathrm{ex}}$. This was reported previously, which showed that the physical-chemistry properties of the active substance to be encapsulated greatly influence the NP characteristics ${ }^{17}$. Particularly in this case, the encapsulation of the extract resulted in a NP size increase. Further, in addition to vitamin $\mathrm{C}$, the extract contains other minor components such as anthocyanins and polyphenols ${ }^{8}$ that may influence the NP characteristics.

The sample $\mathrm{NP}_{\mathrm{ex}}$ when exposed to instability conditions as influence of light and oxygen did not show significant variation in average size. On the other hand, under influence of temperature, it resulted in a considerable increase in size during the 4 days of storage. The mechanism involved is not yet clear, but generally under unfavorable conditions NPs tend to cluster and precipitate ${ }^{12}$. For $\mathrm{NP}_{\mathrm{AA}}$, it was observed that during the storage period (11 days) it did not present significant size variation when exposed to all conditions (Table 3).

The zeta potential for $\mathrm{NP}_{\mathrm{ex}}$ and $\mathrm{NP}_{\mathrm{AA}}$ in the zero day showed positive values (Table 3 ) that is due the cationic character the chitosan polyelectrolyte ${ }^{29,30}$. Such data can spread light on the NP stability, once high zeta potential values $( \pm 30 \mathrm{mV})$ form more stable NP suspensions, since repulsive forces tend to prevent aggregation as a function of interactions with adjacent $\mathrm{NP}^{31}$. For all the samples, in all the conditions tested, it was not observed decrease in the zeta potential values from its initial value (Table 3 ). This indicates the stability of the NP suspension, with no tendency to precipitate, despite the encapsulated vitamin C suffer some degradation.

\subsection{Stability of nanocomposites films}

Similarly found for NP, the NC films submitted to different storage conditions showed improved conservation of vitamin C. For light influence (Figure 2a), compared to the initial value, the encapsulated condition $\left(\mathrm{NC}_{\mathrm{ex}}\right.$ and $\left.\mathrm{NC}_{\mathrm{AA}}\right)$ retained about $62 \%$ of the initial concentration of vitamin $\mathrm{C}$ on the ninth day. This value is high compared to the non-encapsulated control $\left(\mathrm{FC}_{\mathrm{AA}}\right)$, where the concentration reaches $34 \%$ in the final analysis period.

Likewise, when exposed to a temperature of $35^{\circ} \mathrm{C}$, the vitamin $\mathrm{C}$ preservation capacity was more efficient for $\mathrm{NC}$ films (Figure 2b). In this case, they exhibited a concentration equivalent to 78 and $88 \%$ of the initial amount of vitamin $\mathrm{C}$, respectively for the $\mathrm{NC}_{\mathrm{ex}}$ and $\mathrm{NC}_{\mathrm{AA}}$ films at the end of the period while for $\mathrm{CF}_{\mathrm{AA}}$ (GLM + non-encapsulated vitamin C) the degradation rate was higher, maintaining only $45 \%$ of the initial concentration (Figure 2b). In agreement, the stability of vitamin $\mathrm{C}$ under $\mathrm{O}_{2}$ action was higher for the $\mathrm{NC}_{\mathrm{ex}}$ system (Figure 2c), in which the final concentration 


\section{Residue}
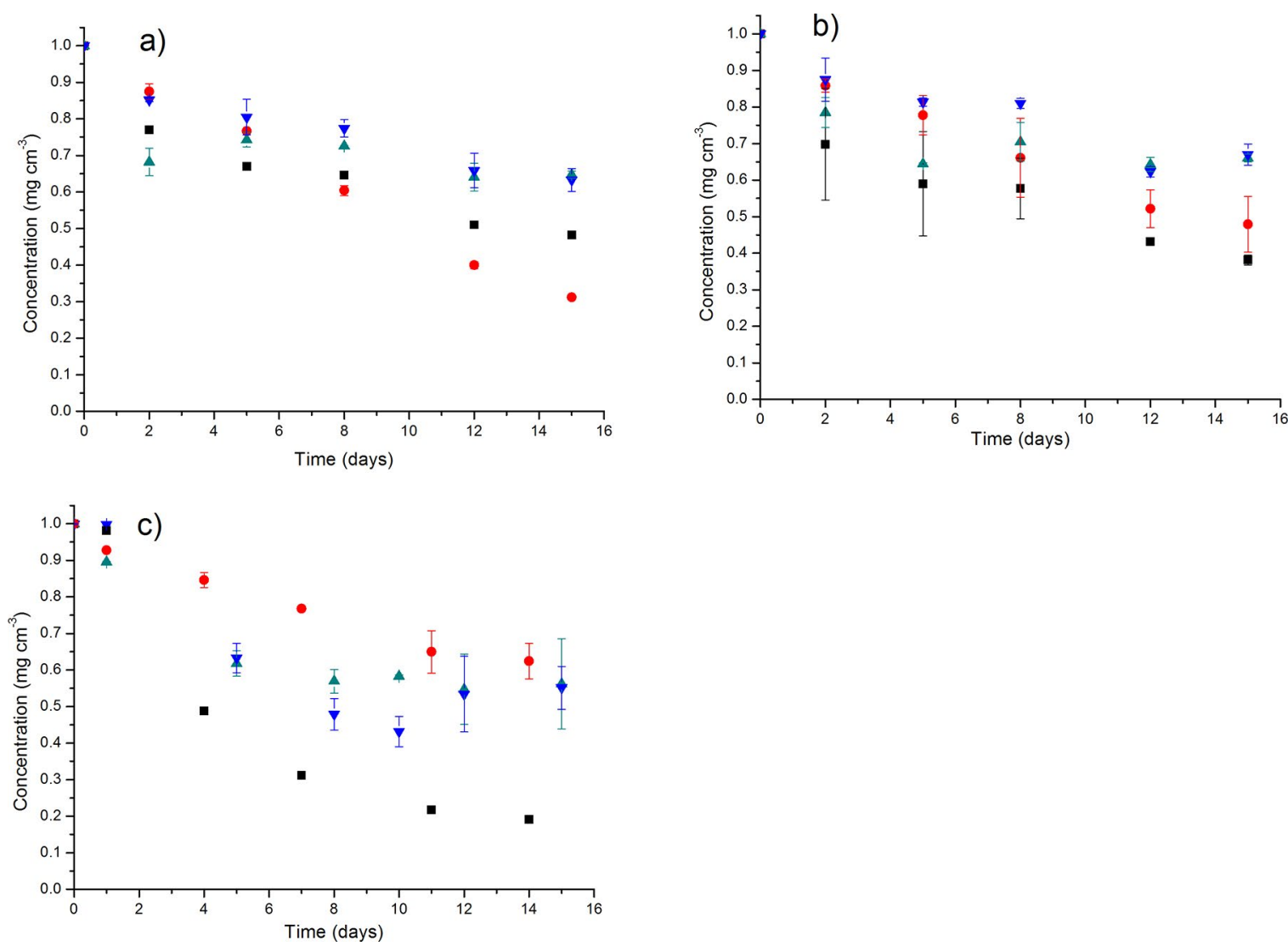

Figure 1. Variation of vitamin $\mathrm{C}$ concentration (normalized) in function of storage time for $\mathrm{AA}_{\mathrm{wt}}(\boldsymbol{\bullet}) ; \mathrm{VC}_{\mathrm{ox}}(\bullet) ; \mathrm{NP}_{\mathrm{ex}}(\boldsymbol{\Delta})$ and $\mathrm{NP}_{\mathrm{AA}}(\boldsymbol{\nabla})$ when exposed to a) light at $25^{\circ} \mathrm{C}$; b) temperature of $35^{\circ} \mathrm{C}$ in absence of light and c) $\mathrm{O}_{2}$ saturation at $25^{\circ} \mathrm{C}$ in absence of light.

Table 3. Variation in size and zeta potential for $\mathrm{NP}_{\mathrm{ex}}$ and $\mathrm{NP}_{\mathrm{AA}}$ under different storability conditions as light, temperature and oxygen. The indices ' $4 \mathrm{~d}$ ', ' $7 \mathrm{~d}$ ' and ' $11 \mathrm{~d}$ ' indicate the number of days stored under these conditions.

\begin{tabular}{ccc}
\hline Systems & Size $(\mathrm{nm})$ & Zeta Potential $(\mathrm{mV})$ \\
\hline $\mathrm{NP}_{\mathrm{ex}}$ & $267 \pm 49$ & $10.4 \pm 0.8$ \\
$\mathrm{NP}_{\mathrm{AA}}$ & $220 \pm 4$ & $21.2 \pm 0.8$ \\
$\mathrm{NP}_{\text {ex }}-$ Light $^{4 \mathrm{~d}}$ & $202 \pm 5$ & $16.2 \pm 0.9$ \\
$\mathrm{NP}_{\text {ex }}-$ Temp $^{4 \mathrm{~d}}$ & $405 \pm 27$ & $18.7 \pm 0.8$ \\
$\mathrm{NP}_{\text {ex }}-$ Oxy $^{4 \mathrm{~d}}$ & $279 \pm 25$ & $12.3 \pm 0.3$ \\
$\mathrm{NP}_{\mathrm{AA}}-$ Light $^{7 \mathrm{~d}}$ & $199.4 \pm 0.4$ & $19.0 \pm 0.6$ \\
$\mathrm{NP}_{\mathrm{AA}}-$ Temp $^{\text {7d }}$ & $231 \pm 8$ & $19.2 \pm 0.6$ \\
$\mathrm{NP}_{\mathrm{AA}}-$ Oxy $^{7 \mathrm{~d}}$ & $213 \pm 2$ & $20.5 \pm 0.6$ \\
$\mathrm{NP}_{\mathrm{AA}}-$ Light $^{11 \mathrm{~d}}$ & $246 \pm 4$ & $18 \pm 9$ \\
$\mathrm{NP}_{\mathrm{AA}}-$ Temp $^{11 \mathrm{~d}}$ & $237 \pm 3$ & $18 \pm 1.0$ \\
$\mathrm{NP}_{\mathrm{AA}}-$ Oxy $^{11 \mathrm{~d}}$ & $224 \pm 3$ & $17.1 \pm 0.9$ \\
\hline
\end{tabular}

reached about $71 \%$ of its initial value. While for the $\mathrm{NC}_{\mathrm{AA}}$ and $\mathrm{CF}_{\mathrm{AA}}$ systems, they degraded at a slightly higher rate, 50 and $39 \%$, respectively. Nanocomposites with nanoencapsulated active substances have not fully explored in the literature, but there is an increase interest of applying nanocomposite films for food preservation ${ }^{32,33}$.

\subsection{Chemical structural analysis of nanocomposites films by FTIR}

The FTIR spectrum of GLM showed typical bands of galactomannan (Figure 3), mainly at 860 and $814 \mathrm{~cm}^{-1}$ that are related with the presence of anomeric configurations ( $\alpha$ and $\beta$ conformers) and glycosidic linkages, attributed to $\alpha$-D-galactopyranose units and $\beta$-D-mannopyranose units, respectively ${ }^{34}$.

The main change in the FTIR spectrum after incorporation of the nanoparticles it is seen at $1590 \mathrm{~cm}^{-1}$ and may be related to the presence of chitosan NP additive. According to literature, for chitosan spectrum, characteristic bands is observed at $1653 \mathrm{~cm}^{-1}$ and $1580 \mathrm{~cm}^{-1}$, corresponding to the amide I and amide II vibrations, respectively ${ }^{35}$.

\subsection{Mechanical analysis}

GLM showed non-linear viscoelastic behavior, exhibiting a stress vs. strain curve typical of brittle material, as found for others polysaccharide as chitosan ${ }^{36}$. GLM exhibited tensile strength and elongation-at-break values respectively near $11 \mathrm{MPa}$ and $2 \%$. Such values is inside the range found for GLM films that showed highly dependent from the source plant as well as the mannose/galactose ratio ${ }^{37}$. 

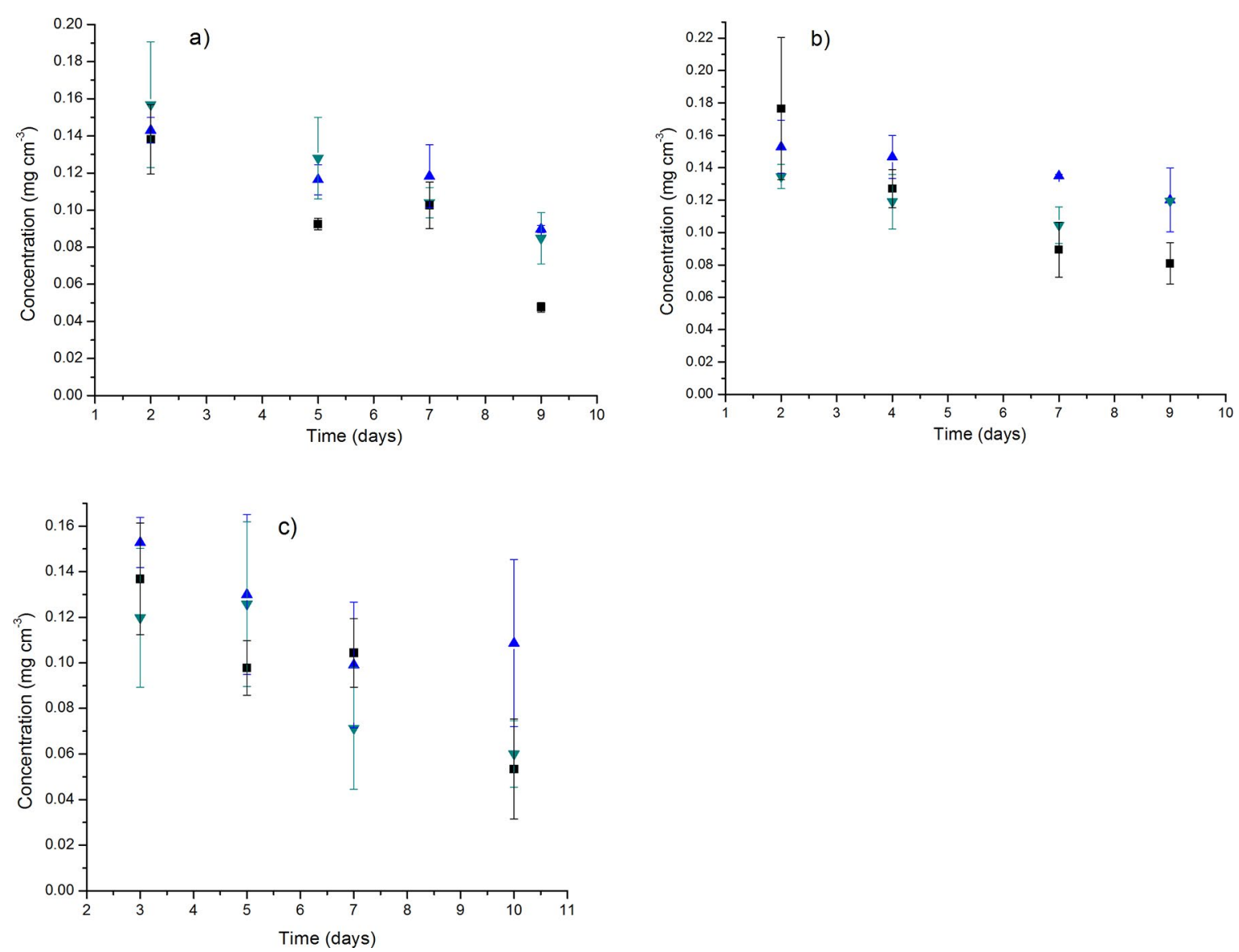

Figure 2. Variation of vitamin $\mathrm{C}$ concentration for $\mathrm{NC}_{\mathrm{ex}}(\boldsymbol{\Delta}), \mathrm{NC}_{\mathrm{AA}}(\boldsymbol{\nabla})$ and $\mathrm{CF}_{\mathrm{AA}}(\boldsymbol{\bullet})$ as a function of storage time when exposed to a) light at $25^{\circ} \mathrm{C}$; b) temperature of $35^{\circ} \mathrm{C}$ in absence of light and c) $\mathrm{O}_{2}$ saturation at $25^{\circ} \mathrm{C}$ in absence of light.

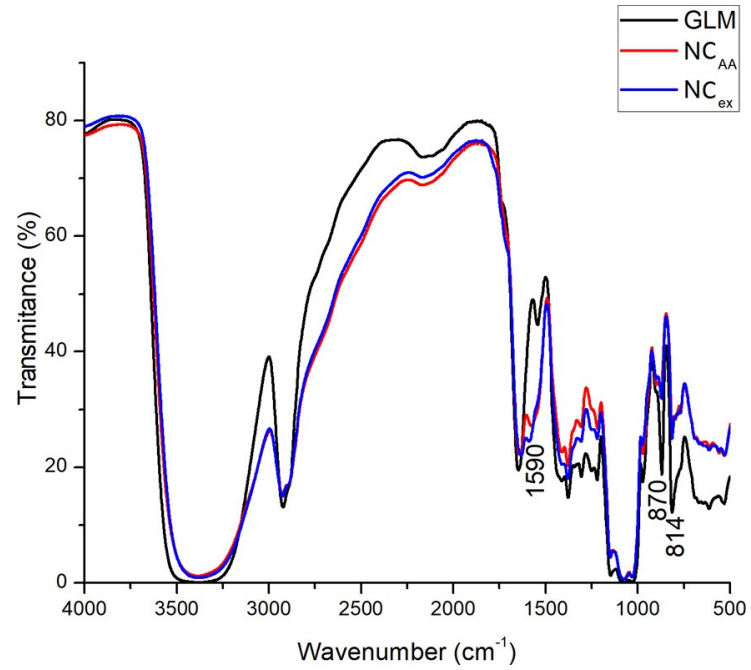

Figure 3. FTIR spectra for pure galactomannan (GLM) and the nanocomposites containing nanoparticles with encapsulated ascorbic acid $\left(\mathrm{NC}_{\mathrm{AA}}\right)$ and acerola extract rich in vitamin $\mathrm{C}\left(\mathrm{NC}_{\mathrm{ex}}\right)$.

The mechanical analysis revealed great difference between the parent polysaccharide GLM and the nanocomposites ones (Figure 4). For the composite films, there were a huge decrease in the tensile strength and a sensible increase in the

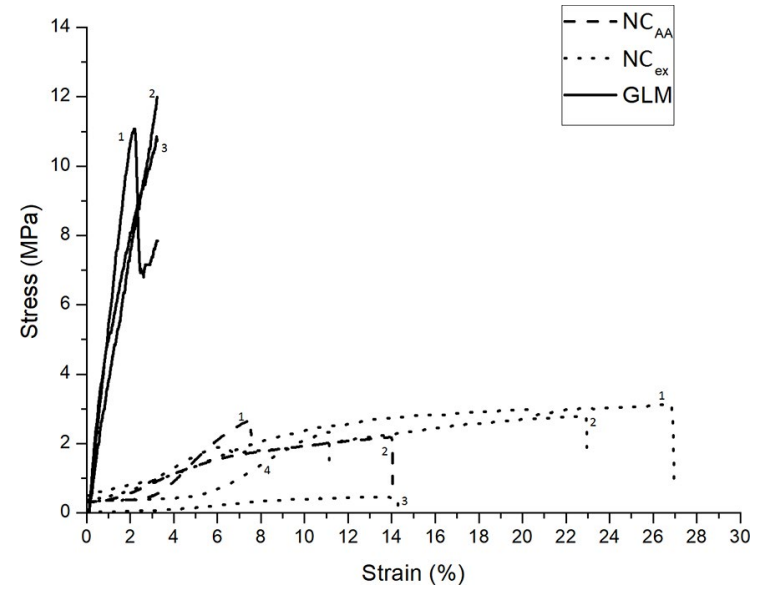

Figure 4. Mechanical behavior of cast films of pure galactomannan (GLM) and the nanocomposites containing nanoparticles with encapsulated ascorbic acid $\left(\mathrm{NC}_{\mathrm{AA}}\right)$ and acerola extract rich in vitamin $\mathrm{C}\left(\mathrm{NC}_{\mathrm{ex}}\right)$.

elongation. For these materials, plastic behavior with great elongation dominates. However, in comparison with pure GLM films, they are less resistant, showing low values for tensile strength. Generally, the nanoparticle addition results in reinforcement improving, with increased tensile strength. It 
was found, for example, for chitosan nanoparticles added to GLM from tara gum ${ }^{38}$ and cellulose derivatives hydroxypropyl methylcellulose $\mathrm{e}^{39}$. However, for those reported materials, despite the tensile strength improvement, the elongation did not experienced sensible improvement or even decreased as found for tara gum nanocomposite ${ }^{38}$. For the present material, the improvement in the elongation was high, what can be attributed to the presence of encapsulated vitamin $\mathrm{C}$. In this case, the nanoencapsulated vitamin $C$, contributed for decreasing the inter-chain galactomannan interaction,

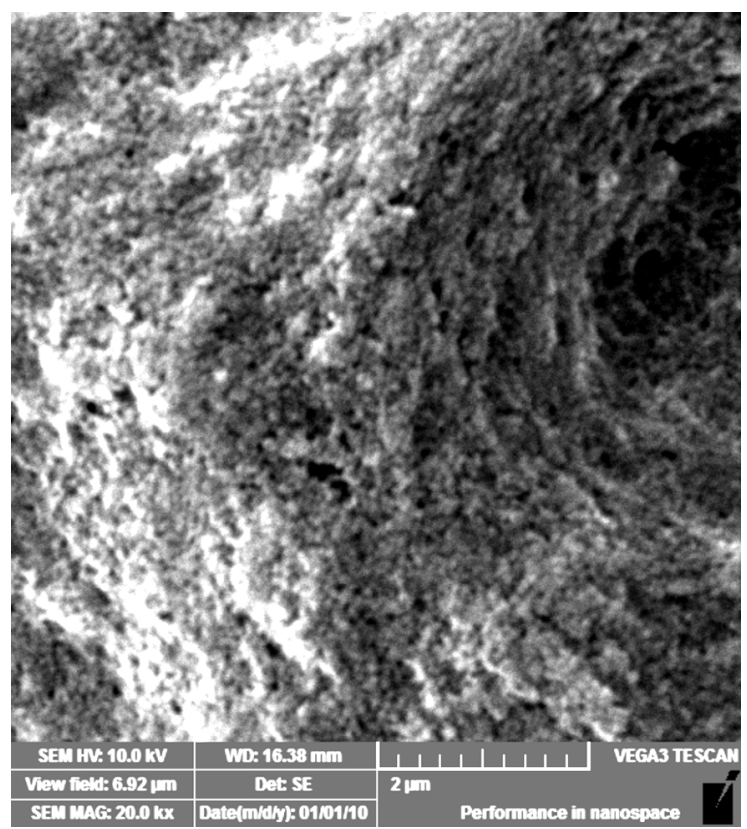

Figure 5. SEM image for $\mathrm{NP}_{\mathrm{AA}}$ isolated by freeze-drying, resuspended in water and deposited on glass sheet. resulting in a less brittle material and good plasticity suitable for food packaging ${ }^{36}$.

\subsection{Morphological analysis}

The isolation process by cryogenic technique resulted in a uniformly distributed NP dispersion (Figure 5). Considering the scale bar, it is clearly identified spherical structure in the range of $100-200 \mathrm{~nm}$. In this way, the NP size distribution is in agreement with that found for DLS measurement.

The GLM film (without inclusion of NP) showed an irregular and rough surface typical of formation of agglomeration (Figure 6a). Such irregularities were also observed even at high magnification image (Figure 6b). In a previously reported study, the GLM exhibited a smoothly, uniform and compact structure ${ }^{40}$. On the other hand, another work with GLM nanocomposite reported fibers structure on the film surface by SEM, acquiring, however, a smooth aspect after addition of glycerol $^{41}$. The surface film morphology can vary greatly depending on several factors, mainly the sample preparation. However, the polysaccharide chains in solution can adopt different conformation in function of the concentration $^{42}$. For high concentration, the polysaccharide chains shift from an extended conformation to a coiled one, resulting in a colloidal system. This is expected to occur during the casting film, explaining such rugosity in morphology.

After the addition of NP, the film morphology changed sensible (Figure 7). Comparing $\mathrm{NC}_{\mathrm{AA}}$ with GLM morphology, it lost that agglomerate like aspect, showing, however, an irregular surface (Figure 7a). Considering the chain conformation in solution, the addition of NP will influence greatly its conformation, reflecting in the pattern adopted in the solid state $^{39}$. At high magnification image, it is clearly identified

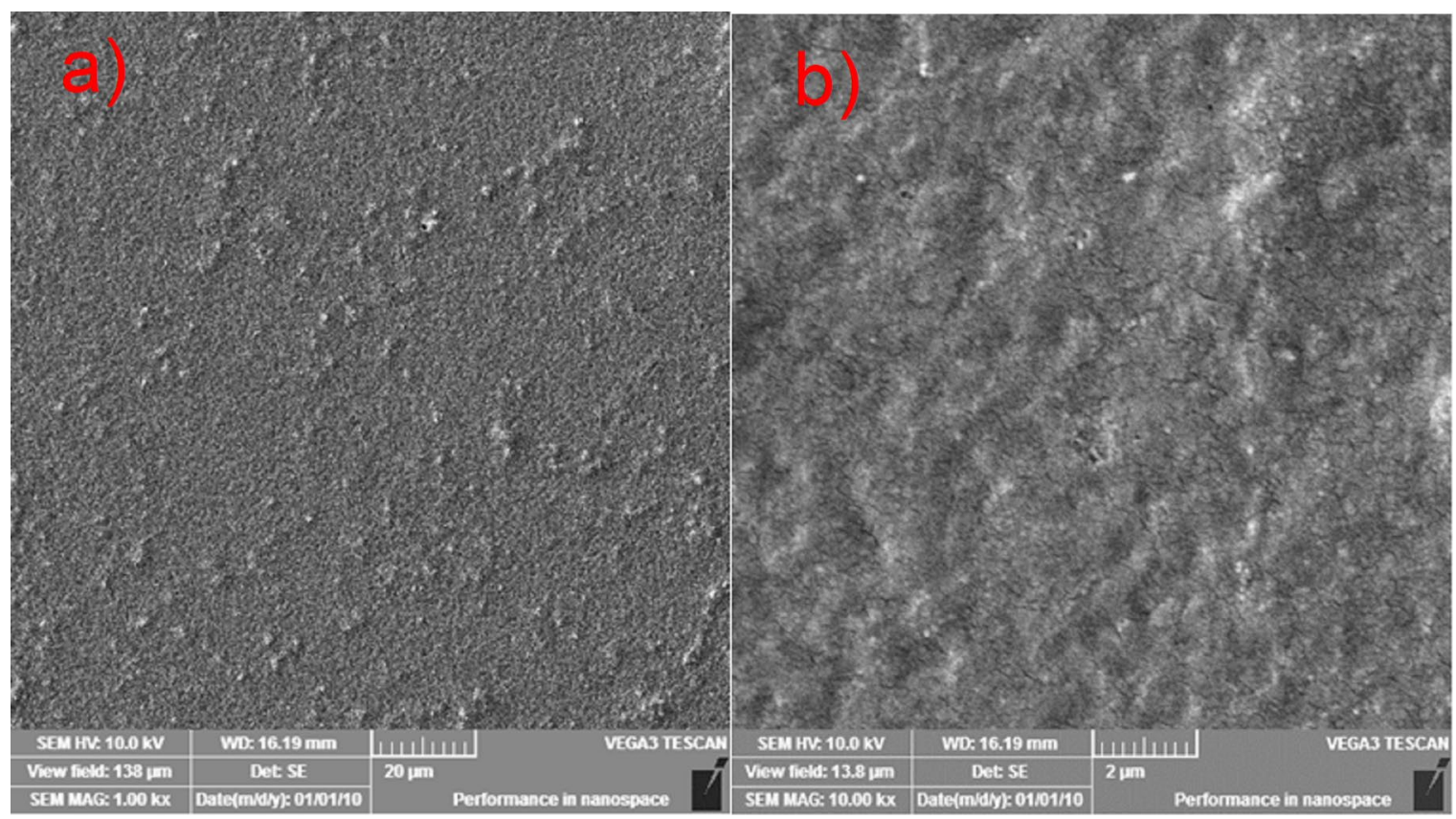

Figure 6. SEM images for GLM film cast on glass sheet at two magnifications a) 1,000X and b) 10,000X. 


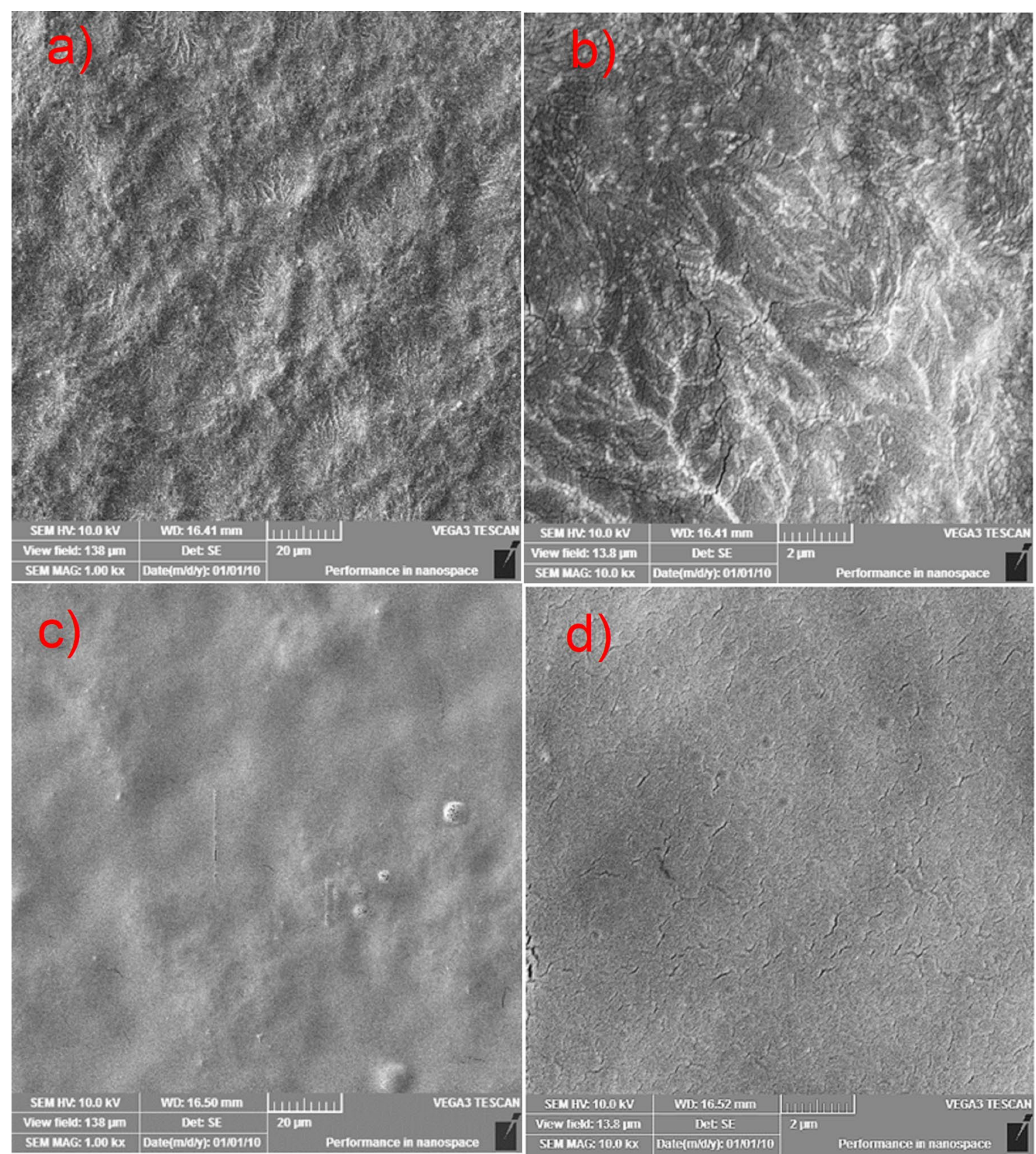

Figure 7. $\mathrm{SEM}$ images for $\mathrm{NC}_{\mathrm{AA}}(\mathrm{a}, \mathrm{b})$ and $\mathrm{NC}_{\mathrm{ex}}(\mathrm{c}, \mathrm{d})$ films cast on glass sheet at two magnifications $1,000 \mathrm{X}(\mathrm{a}, \mathrm{c})$ and 10,000X (b, d).

the NP structure with good distribution in the polysaccharide matrix (Figure 7b). A good dispersion in the nanocomposites is related to the affinity between the nanoreinforcement and the matrix having similar chemical structure and hydrophilic nature ${ }^{43,44}$. In a similar way, $\mathrm{NC}_{\mathrm{ex}}$ also presented difference in surface morphology in comparison with the parent GML film (Figure 7c). However, its morphology was smoother than that observed for $\mathrm{NC}_{\mathrm{AA}}$. It is not clear what induced such aspect, but others components present in the acerola extract can influence the polysaccharide chain conformation during the cast film. At high magnification image, it is possible to identify some NP structure in the polysaccharide matrix (Figure 7b), however, with low contrast in comparison with $\mathrm{NC}_{\mathrm{AA}}$. In this case, the $\mathrm{NP}_{\mathrm{ex}}$ structure looks to be more integrated in the polysaccharide matrix, losing its boundaries.

\section{Conclusion}

The system composed of chitosan in aqueous solution of $\mathrm{HCl}$ reveled as a potential alternative for extracting vitamin $\mathrm{C}$ from the agroindustrial residue of the acerola processing. Further, the nanoencapsulation by the ionotropic process 
was effective in to preserve such extracted vitamin. Several comparative experiments under adverse conditions such as light incidence, temperature and oxygen influence attested the preservation capacity of the nanoencapsulated system.

Galactomannan polysaccharide showed good filmogenic property suitable for preparation of nanocomposites. The nanocomposite films made from galactomannan and nanoencapsulated vitamin $\mathrm{C}$ presented additional preservation capacity even in adverse conditions such as under the influence of light, temperature and oxygen.

The morphological analysis showed huge difference between the nanocomposites and the parent galactomannan film. The analysis also attested the good distribution of the NP charge into the polysaccharide matrix.

These results highlight the potentiality of application of these materials as active packaging in forms of edible film.

\section{Acknowledgement}

The authors are thankful to Rede AgroNano (Embrapa); FACEPE and CNPq for the financial support. In addition, special thanks to Adriana Coatrini Thomazi (Embrapa Instrumentação) and Ginetton Ferreira Tavares (Laboratório de Ciência dos Materiais - Univasf) to collect the DLS and SEM data, respectively.

\section{References}

1. Carvalho EAS, Marques VR, Rodrigues RJS, Ribeiro CEG, Monteiro SN, Vieira CMF. Development of Epoxy Matrix Artificial Stone Incorporated with Sintering Residue from Steelmaking Industry. Materials Research. 2015;18(Suppl 2):235-239.

2. Caetano ACS, Melo EA, Lima VLAG, Maciel MIS, Araújo CR. Extração de antioxidantes de resíduos agroindustriais de acerola. Brazilian Journal Food Technology. 2009;12(2):155-160.

3. Yammine S, Brianceau S, Manteau S, Turk M, Ghidossi R, Vorobiev E, et al. Extraction and purification of high added value compounds from by-products of the winemaking chain using alternative/nonconventional processes/technologies. Critical Reviews in Food Science and Nutrition. 2018;58(8):1375-1390.

4. Gabaston J, Richard T, Cluzet S, Pinto AP, Dufour MC, CorioCostet MF, et al. Pinus pinaster Knot: A Source of Polyphenols Against Plasmopara viticola. Journal of Agricultural and Food Chemistry. 2017;65(40):8884-8891.

5. Castro ACCM, Oda FB, Almeida-Cincotto MGJ, Davanço MG, Chiari-Andréo BG, Cicarelli RMB, et al. Green coffee seed residue: A sustainable source of antioxidant compounds. Food Chemistry. 2018;246:48-57.

6. Joanitti GA, Silva LP. The emerging potential of by-products as platforms for drug delivery systems. Current Drug Targets. 2014; 15(5):478-485.

7. Moreira GEG. Obtenção e caracterização do extrato microencapsulado de resíduo agroindustrial de acerola. [Dissertation]. Natal: Federal University of Rio Grande do Norte; 2008.
8. Costa ACS. Qualidade e atividade antioxidante na porção comestivel e resíduos do processamento de acerola produzida no submédio do Vale do São Francisco. [Dissertation]. Areia: Federal University of Paraíba; 2012.

9. Sapei L, Hwa L. Study on the Kinetics of Vitamin C Degradation in Fresh Strawberry Juices. Procedia Chemistry. 2014;9:62-68.

10. Del-Valle V, Hernández-Muñoz P, Catalá R, Gavara R. Optimization of an equilibrium modified atmosphere packaging (EMAP) for minimally processed mandarin segments. Journal of Food Engineering. 2009;91(3):474-481.

11. Gregory JF, III. Chemical Changes of Vitamins During Food Processing. In: Richardson T, Finley JW, eds. Chemical Changes in Food During Processing. Boston: Springer; 1985. p. 373-408.

12. de Britto D, Moura MR, Aouada FA, Pinola FG, Lundstedt LM, Assis $\mathrm{OBG}$, et al. Entrapment characteristics of hydrosoluble vitamins loaded into chitosan and N,N,N-trimethyl chitosan nanoparticles. Macromolecular Research. 2014;22(12):1261-1267.

13. Sekhon BS. Food nanotechnology - an overview. Nanotechnology, Science and Applications. 2010;(3):1-15.

14. Dupeyrón Martell DR, Rieumont Briones J, González Hurtado M, del Real López A, Castaño Meneses VM. Effect of solvents on the morphological characterization of enteric nanoparticles. Materials Research. 2009;12(4):405-410.

15. Farias MC, de Moura ML, Andrade L, Leão MHMR. Encapsulation of the alpha-tocopherol in a glassy food model matrix. Materials Research. 2007;10(1):57-62.

16. Gan Q, Wang T, Cochrane C, McCarron P. Modulation of surface charge, particle size and morphological properties of chitosan-TPP nanoparticles intended for gene delivery. Colloids and Surfaces B: Interfaces. 2005;44(2-3):65-73.

17. de Britto D, de Moura MR, Aouada FA, Mattoso LHC, Assis OBG N,N,N-trimethyl chitosan nanoparticles as a vitamin carrier system. Food Hydrocolloids. 2012;27(2):487-493.

18. de Britto D, Assis OBG. Chemical, biochemical, and microbiological aspects of chitosan quaternary salt as active coating on sliced apples. Food Science and Technology. 2012;32(3):599-605.

19. Cerqueira MA, Bourbon AI, Pinheiro AC, Martins JT, Souza BWS, Teixeira JA, et al. Galactomannans use in the development of edible films/coatings for food applications. Trends in Food Science \& Technology. 2011;22(12):662-671.

20. Bento JF, Mazzaro I, Silva LMA, Moreira RA, Ferreira MLC, Reicher F, et al. Diverse patterns of cell wall mannan/galactomannan occurrence in seeds of the Leguminosae. Carbohydrate Polymers. 2013;92(1):192-199.

21. Pegado CMA, Andrade LA, Félix LP, Pereira IM. Efeitos da invasão biológica de algaroba-Prosopis juliflora (Sw.) DC. sobre a composição e a estrutura do estrato arbustivo-arbóreo da caatinga no Município de Monteiro, PB, Brasil. Acta Botanica Brasilica. 2006;20(4):887-898.

22. Souza Filho M, Nascimento RM, Cavalcante FL, Rosa MDF, Morais JPS, Feitosa JPA, et al. Extração e caracterização de galactomanana de vagens de Algaroba (Prosopis juliflora). Embrapa Agroindústria Tropical-Comunicado Técnico (INFOTECA-E) [Internet]. 2013. Available from: $<\mathrm{http}: / / \mathrm{www}$.infoteca.cnptia. embrapa.br/bitstream/doc/981685/1/COT13007.pdf $>$. 
23. Vendramini AL, Trugo LC. Chemical composition of acerola fruit (Malpighia punicifolia L.) at three stages of maturity. Food Chemistry. 2000;71(2):195-198.

24. Núcleo de Estudos e Pesquisas em Alimentação - NEPA / Universidade Estadual de Campinas - UNICAMP. Tabela brasileira de composição de alimentos-TACO. [Internet]. 2011. Available from: <http://www.cfn.org.br/wpcontent/ uploads/2017/03/taco_4_edicao_ampliada_e_revisada.pdf $>$.

25. Alishahi A, Mirvaghefi A, Tehrani MR, Farahmand H, Shojaosadati SA, Dorkoosh FA, et al. Shelf life and delivery enhancement of vitamin $\mathrm{C}$ using chitosan nanoparticles. Food Chemistry. 2011;126(3):935-940.

26. Britto D, Pinola FG, Mattoso LCH, Assis OBG. Analysis of thermal and aqueous suspension stabilities of chitosan based nanoencapsulated vitamins. Quimica Nova. 2016;39(9):11261130 .

27. Jimenez-Fernandez E, Ruyra A, Roher N, Zuasti E, Infante C, Fernández Díaz C. Nanoparticles as a novel delivery system for vitamin $\mathrm{C}$ administration in aquaculture. Aquaculture. 2014;432:426-433.

28. Wu XM, Branford-White CJ, Yu DG, Chatterton NP, Zhu LM. Preparation of core-shell PAN nanofibers encapsulated a-tocopherol acetate and ascorbic acid 2-phosphate for photoprotection. Colloids and Surfaces B: Biointerfaces. 2011;82:247-252.

29. Gan Q, Wang T. Chitosan nanoparticle as protein delivery carrier-systematic examination of fabrication conditions for efficient loading and release. Colloids and Surfaces B: Biointerfaces. 2007;59(1):24-34.

30. Chen F, Zhang ZR, Huang Y. Evaluation and modification of $\mathrm{N}$-trimethyl chitosan chloride nanoparticles as protein carriers. International Journal of Pharmaceutics. 2007;336(1):166-173.

31. Schaffazick SR, Guterres SS, Freitas LL, Pohlmann AR. Caracterização e estabilidade físico-química de sistemas poliméricos nanoparticulados para administração de fármacos. Química Nova. 2003;26(5):726-737.

32. Sarkar P, Choudhary R, Panigrahi S, Syed I, Sivapratha S, Dhumat CV. Nano-inspired systems in food technology and packaging. Environmental Chemistry Letters. 2017;15(4):607622.

33. Priya DS, Suriyaprabha R, Yuvakkumar R, Rajendran V. Chitosan-incorporated different nanocomposite HPMC films for food preservation. Journal of Nanoparticle Research. 2014;16(2):2248.
34. Bouttier-Figueroa DC, Quevedo-Lopez MA, Rosas-Durazo A, Sotelo-Lerma M. Hydrothermal technique for isolation of galactomannan from seeds of sonoran mezquite (Prosopis spp.). Revista Mexicana de Ingeniería Química. 2017;16(2):457-465.

35. de Britto D, Campana-Filho SP. Kinetics of the thermal degradation of chitosan. Thermochimica Acta. 2007;465(1-2):73-82.

36. de Britto D, de Assis OBG. Synthesis and mechanical properties of quaternary salts of chitosan-based films for food application. International Journal of Biological Macromolecules. 2007;41(2):198-203.

37. dos Santos VRF, Souza BWS, Teixeira JA, Vicente AA, Cerqueira MA. Relationship between galactomannan structure and physicochemical properties of films produced thereof. Journal of Food Science and Technology. 2015;52(12):8292-8299.

38. Antoniou J, Liu F, Majeed H, Zhong F. Characterization of tara gum edible films incorporated with bulk chitosan and chitosan nanoparticles: A comparative study. Food Hydrocolloids. 2015;44:309-319.

39. de Moura MR, Avena-Bustillos RJ, McHugh TH, Krochta JM, Mattoso LH. Properties of novel hydroxypropyl methylcellulose films containing chitosan nanoparticles. Journal of Food Science. 2008;73(7):N31-N37.

40. Cerqueira MA, Souza BWS, Martins JT, Teixeira JA, Vicente AA. Seed extracts of Gleditsia triacanthos: Functional properties evaluation and incorporation into galactomannan films. Food Research International. 2010;43(8):2031-2038.

41. Souza NDG, Freire RM, Cunha AP, da Silva MAS, Mazzetto SE, Sombra ASB, et al. New magnetic nanobiocomposite based in galactomannan/glycerol and superparamagnetic nanoparticles. Materials Chemistry and Physics. 2015;156:113-120.

42. de Britto D, Assis OBG. Hydrophilic and morphological aspects of films based on quaternary salts of chitosan for edible applications. Packaging Technology and Science. 2010;23(2):111-119.

43. Riva GH, García-Estrada J, Vega B, López-Dellamary F, Hérnandez ME, Silva JA. Cellulose-Chitosan Nanocomposites: Evaluation of Physical, Mechanical and Biological Properties. In: Poletto M, ed. Cellulose - Fundamental Aspects And Current Trends. London: InTechOpen; 2015.

44. El Miri N, Abdelouahdi K, Barakat A, Zahouily M, Fihri A, Solhy A, et al. Bio-nanocomposite films reinforced with cellulose nanocrystals: Rheology of film-forming solutions, transparency, water vapor barrier and tensile properties of films. Carbohydrate Polymers. 2015;129:156-167. 